\title{
Role of Adhesion Molecules in Leukocyte Invasion
}

\author{
亀田秀 人*
}

\section{I. 発見の経緯}

発生期における器官形成からすでに, 細胞同士の対話が 始まっている，細胞は周囲の基質から，あるいは細胞間相 互作用により得られる膨大な情報を処理しながら生きてい る.このことは古くから気づかれていたが, 分子レベルで 解明されるに至ったのはこの 10 年間である. 細胞間相互作 用のなかでも，生体への侵襲に即応して白血球が流血中か ら血管外へ浸潤していく過程は, 生命現象のなかでももつ とも劇的かつ重要なものである.

この分子機構の発見に 20 年以上さきだち, リンパ球が 流血中よりリンパ節へ戻る “ホーミング現象”が知られて いた. 流血中の他の白血球や赤血球と異なり, さらに特定 のリンパ組織由来のリンパ球はそのリンパ組織に帰る傾向 を示すのはなぜかとの問いに対して, リンパ球の表面に特 異的に発現する分子,すなわち “ホーミングレセプター”が 探究された。 そして 1983 年モノクローナル抗体 MEL-14 で認識される分子 (現在の L-セレクチン) が発見された。 一方，血管内皮細胞は局所の炎症に反応して表情を変化さ せる. 1985 年内皮細胞をトロンビンで刺激すると数分で, IL-1 P TNF $\alpha$ で刺激すると数時間で白血球の接着性が光 進することが相次いで報告された。前者に関しては，1984 年に活性化した血小板のみに反応するモノクローナル抗体 の対応抗原が, PADGEM (platelet activation dependent granule-external membrane protein), GMP-140 (granule

\section{${ }^{*}$ 慶應義塾大学医学部内科}

Hideto Kameda: Department of Internal Medicine, Keio University School of Medicine, Tokyo, Japan.

Abbreviation : ICAM-1; intercellular adhesion molecule-1. ICAM-2 ; intercellular adhesion molecule-2. VCAM-1 ; vascular cell adhesion molecule-1. PECAM-1; plateletendothelial cell adhesion molecule-1. LPS ; lipopolysaccharide. TNF $\alpha$; tumor necrosis factor $\alpha$. VLA-4; very late antigen-4. LFA-1; leukocyte function-associated antigen-1. TGF- $\beta$; transforming growth factor- $\beta$.

原稿受取日：1997 年 1 月 22 日

membrane protein-140) として二つのグループからほほ同 時に報告されていたが, 1989 年この分子が血管内皮細胞に も発現し, トロンビン刺激による白血球接着を説明する分 子 (現在のP-セレクチン) であることが判明した。後者に 関しては, 1987 年炎症性サイトカイン刺激により内皮細胞 表面に発現誘導される分子を認識し，白血球の接着を抑制 するモノクローナル抗体が作製され，この分子は ELAM-1 (endothelial-leukocyte adhesion molecule-1, 現在の呼称では E-セレクチン) として報告された. 1989 年にこれら三つの 分子の cDNA が相次いでクローニングされた結果, 驚いた ことにいずれも $\mathrm{N}$ 末端にレクチン (lectin) 様構造をもつ 共通した遺伝子配列であることが判明し, 対応する分子を 選択的 (selective) に認識するとの意も含めて selectin と命 名された1).

他方, 1966 年免疫グロブリン $(\mathrm{Ig})$ の $\mathrm{H}$ 鎖および $\mathrm{L}$ 鎖の 定常部位のアミノ酸配列を検討し, 共通した配列を発見, その反復構造をとっていることが提唱された。ささらにその 約 100 個のアミノ酸からなる共通配列は, 二つの $\beta$ シート にはさまれ, ジスルフィド結合により安定した構造をとっ ていることが判明した。その後 $\beta_{2}$ ミクログロブリンも同様 の構造を有することがわかり, 以後は $\mathrm{T}$ 細胞の表面分子の 検討が精力的に行われ, 1984 年の T 細胞レセプターの構造 解明という画期的な業績をはじめ, ヒト白血球抗原 (HLA)-class I と II, CD2 などが同様の構造をもつことが明 らかにされ，Igスーパーファミリーと総称されるに至っ た2).

インテグリンの歴史は, 細胞外基質の一つフィブロネク チン (FN) の細胞接着領域の解析から, 1984 年 Arg-GlyAsp (RGD) という特有のアミノ酸配列を細胞が認識して いることを発見したのに端を発する。1986 年 Hynes は FN 受容体の cDNA クローニングに成功し,この細胞膜貫通型 構造を有する蛋白を, 細胞内外を統合 (integrate) する意で “インテグリン”と命名した. その後ビトロネクチン受容体 など，多くの細胞外基質が共有する RGD 配列を認識する ものを中心として, 同様の構造をもつ接着分子群が次々と 同定され，インテグリンはその総称とされるに至った². 
さらにカドヘリン $(\mathrm{N} \cdot \mathrm{E} ・ \mathrm{P}-$ カドヘリン $)$ やプロテオグ リカン (CD44 など), シアロムチン (CD34 など) などの 接着分子ファミリーが見出され, 現在では多様な系統から なる大家族を構成している，このうち本稿では，白血球の 血管外浸潤に特に重要とされる, セレクチン・インテグリ ン・Igスーパーファミリーに焦点をあて, 動脈硬化の病態 との関連も含めて概説する.

\section{II. 細胞接着分子の構造 (Fig. 1)}

\section{1) セレクチンファミリー}

$\mathrm{N}$ 末端に C-type レクチン様構造領域 $\left(\mathrm{Ca}^{2+}\right.$ 依存性に特 定の糖鎖と結合), さらに EGF 椂構造領域 (結合領域の立 体構造保持), 補体調節蛋白様領域 (補体との結合性は知ら れておらず, 機能は不明), 細胞膜貫通領域, 細胞質内領域 と繫がり, 補体調節蛋白様領域における基本構造の反復が L-セレクチンでは 2 回, E-セレクチンでは 6 回, P-セレクチ
ンでは 9 回 (ただし，7番目を欠損したものと細胞膜貫通 領域を欠損したものとの 2 種類の alternative splicing 産物 が存在) と異なっており，74 kD〜 $140 \mathrm{kD}$ と分子量が異な る.

2) インテグリンファミリー

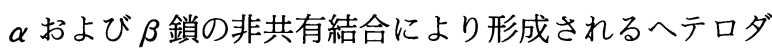
イマー構造をとる分子群である. $\alpha$ 鎖は $\alpha_{1} \sim \alpha_{9}, \alpha_{\mathrm{L}, \mathrm{M}, \mathrm{X}}, \alpha_{\mathrm{V}}$, $\alpha_{\mathrm{HML}}, \alpha_{\mathrm{IIb}}$ など 15 種類, $\beta$ 鎖は $\beta_{1} \sim \beta_{8}$ の 8 種類がみつかつ ており, 白血球の血管外浸潤で重要なのは VLA-4 $\left(\alpha_{4} \beta_{1}\right)$, LFA-1 $\left(\alpha_{\mathrm{L}} \beta_{2}\right)$, Mac-1 $\left(\alpha_{\mathrm{M}} \beta_{2}\right)$ である. $\alpha$ 鎖の細胞外領域に 2 価イオン結合配列 (DXDXDGXXD, D : アスパラギン 酸, $\mathrm{G}$ : グリシン, $\mathrm{X}$ : 不定) を有し, 一方 $\beta$ 鎤の細胞質領 域はタリン， $\alpha$-アクチニンなどの細胞骨格蛋白に結合して いる3).

3) 免疫グロブリン $(\mathbf{I g})$ スーパーファミリー 60〜80 個のアミノ酸がシステイン残基間のジスルフィ

$$
\operatorname{Ig} \text { I ーパーファミリー インテグリン インクチン }
$$

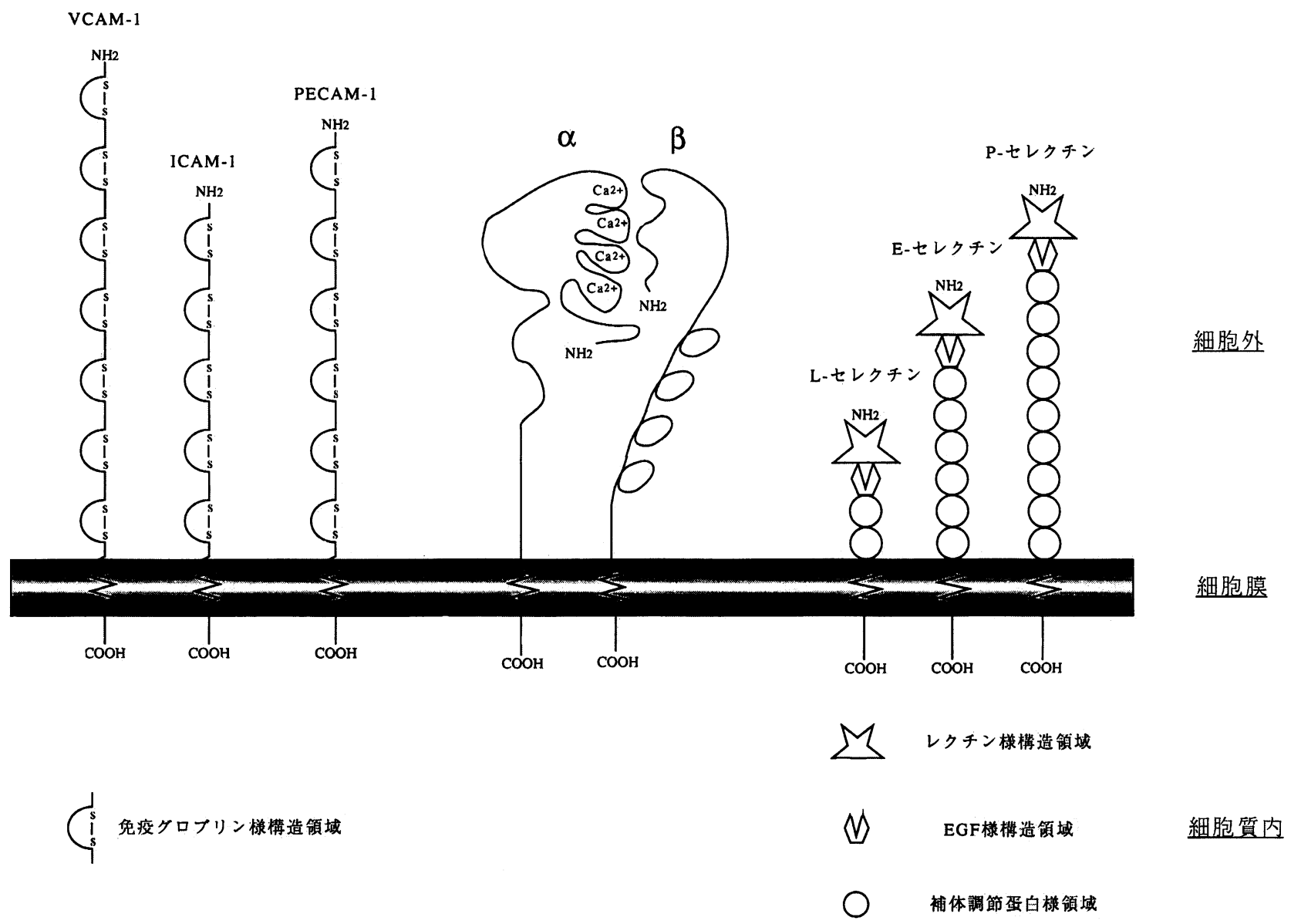

Fig. 1 白血球の血管外浸潤に関与する主な細胞接着分子の構造. 
ド結合により形成する特徵的構造を有する接着分子群であ り, ICAM-1 (5), ICAM-2 (2), ICAM-3 (2) や VCAM-1 (6 または 7, alternative splicingによる), PECAM-1 (6) など がこれに属する〈( ) 内の数字は Ig 様構造の数を示す〉.

\section{III. 遺 伝子}

\section{1) 遺伝子座}

遺伝子座としてはセレクチンファミリーは $1 \mathrm{q}$ に約 300 $\mathrm{kb}$ の範囲に集積して存在する. インテグリンファミリーは $\alpha \cdot \beta$ 鎖とも多様で, たとえば $\alpha_{4,6, \mathrm{v}}$ が 2 番, $\alpha_{1,2}$ が 5 番, $\alpha_{5}$ は $12 \mathrm{q}, \alpha_{3}$ は 17 番, $\alpha_{\mathrm{L}, \mathrm{M}, \mathrm{x}}$ は $16 \mathrm{p}, \beta_{1}$ は $10 \mathrm{p}, \beta_{2}$ は $21 \mathrm{q}, \beta_{3}$ は $17 \mathrm{q}$ に存在する. Ig スーパーファミリーの分子群も ICAM-1 は 19 番, ICAM-2 は 17 q, VCAM-1 は $1 \mathrm{p}$ とそれ ぞれ異なる局在を示す。

\section{2) 遺伝子発現}

遺伝子発現の調節に関しては，白血球の血管外浸潤に関 与する接着分子の多くは, TNF $\alpha$, IL-1 などの炎症性サイ トカインや LPSにより誘導される.しかし異なる経時的変 化を示し, E-セレクチンは 4 6 時間, ICAM-1 や VCAM-1 は 24〜 48 時間で発現は最大となる.リンパ球における VLA-4 の発現に至っては mitogen ${ }^{+}$IL-2 刺激からじつに 2 〜 4 週後に最大となる. 転写活性の調節では，たとえば Eセレクチンの場合, プロモーター領域の NFが重要とされる. GAGACC という遺伝子配列をコアシー クエンスとするずり応力応答配列 (shear stress responsive element: SSRE) が同定され, ICAM-1 などのプロモー 夕一領域に存在し，なんらかの転写因子が結合することで 転写を促進すると考えられている.しかし, SSREをもたな いVCAM-1ではずり応力により逆に転写は抑制され，こ の機構も不明である。

\section{IV. 生理的機能}

\section{1) 接着分子の対応抗原}

(1) セレクチン

セレクチンの構造からリガンドが糖鎖であることが推 定され，糖鎖の酵素的修飾，モノクローナル抗体や可溶型 分子, 糖鎖による接着阻止実験により解析が進められた。 その結果, SLe-X, SLe-a, Le-X などを認識することが明ら かとなった。次いで, かかる糖鎖をもつ分子 (糖蛋白) の同

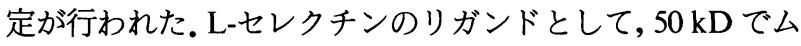
チン様構造をもつ GlyCAM-1 (glycosylation-dependent cell adhesion molecule-1), 58〜 66 kD で Ig 様およびムチン様構 造領域をもつ MAdCAM-1 (mucosal addressin cell adhesion molecule-1) がcDNA クローニングされた。さらに $90 \mathrm{kD}$ の糖蛋白 (sgp90, GlyCAM-2) は CD34 と同一の蛋白構造 を有することが示された。しかしこの三つのリガンド分子
それぞれの役割の詳細は不明である，P-セレクチンのリガ ンドとして $220 \mathrm{kD}$ のムチン様構造を有する homodimer 分子である PSGL-1 (P-selectin glycoprotein ligand-1) が cDNA クローニングされた。この分子は E-セレクチンのリ ガンドともなる.さらに 1995 年になり E-セレクチンとは 結合し, P-セレクチンとは結合しない $150 \mathrm{kD}$ の分子 (Eselectin ligand-1： ESL-1) が報告されている4).

(2) インテグリン

インテグリンのリガンドは，基質と Ig スーパーファミ リーの接着分子とに大別される. インテグリンの $\alpha$ 鎖には 3〜4カ所の 2 価イオン結合領域 (EF hand 構造) が存在 し, リガンド結合は 2 価イオン $\left(\mathrm{Ca}^{2+}, \mathrm{Mg}^{2+}, \mathrm{Mn}^{2+}\right)$ 依存 性である. 白血球の血管外浸潤において重要なのは, VLA4 と VCAM-1 および LFA-1・Mac-1 と ICAM-1 との結合, すなわち Igスーパーファミリーの分子との結合である.

(3) Igスーパーファミリー

Igスーパーファミリーの結合では, 前述のインテグリン との結合の他に，同族分子間の結合がある.この場合， PECAM-1 のようなホモ分子結合 (ただし血管内皮細胞間 あるいは白血球一内皮細胞間と発現細胞のパターンはホ モ・ヘテロともあり得る)，および CD28 と CD80·CD86の 結合のようなへテロ分子結合の両者がみられる.

\section{2）接着分子の機能制御}

接着分子は下記の調節をうけている.

(1) 細胞表面の発現量 (量的変化)

(1) mRNA の転写などによる蛋白合成 例：E-セレク チンにおける IL-1・TNF $\alpha$ による転写促進, TGF- $\beta$ による 転写抑制など

(2) 分子の細胞内局在変化 例 : P-セレクチンにおけ るトロンビン・ヒスタミンによる顆粒膜から細胞膜表面へ の移行など

(3) Shedding 例：L-セレクチンにおける白血球活性 化に伴う酵素的分解による脱落など

（2）接着親和性・結合力の変化 (質的変化)

例：LFA-1 における白血球活性化に伴う avidity 増強な ど

接着分子の種類の豊富さのみならず，かかる多様な機能 制御機構の存在が，次に述べる多段階反応である白血球の 血管外浸潤を規定しているのである。

\section{3） 白血球の血管外浸潤の過程 (Fig. 2)}

白血球の血管外浸潤は少なくとも, (1) ローリング現 象, (2) 白血球の活性化, (3) 白血球の強固な粘着, (4) 血 管内皮細胞間陌の通過, の4 段階に分けられる5). (1) の過 程は生理的には白血球の L-セレクチンによりわずかに行 われているが, 炎症により局所の細静脈内皮細胞の活性化 に伴い表面発現した P-セレクチンあるいは E-セレクチン 
1. ローリング現象

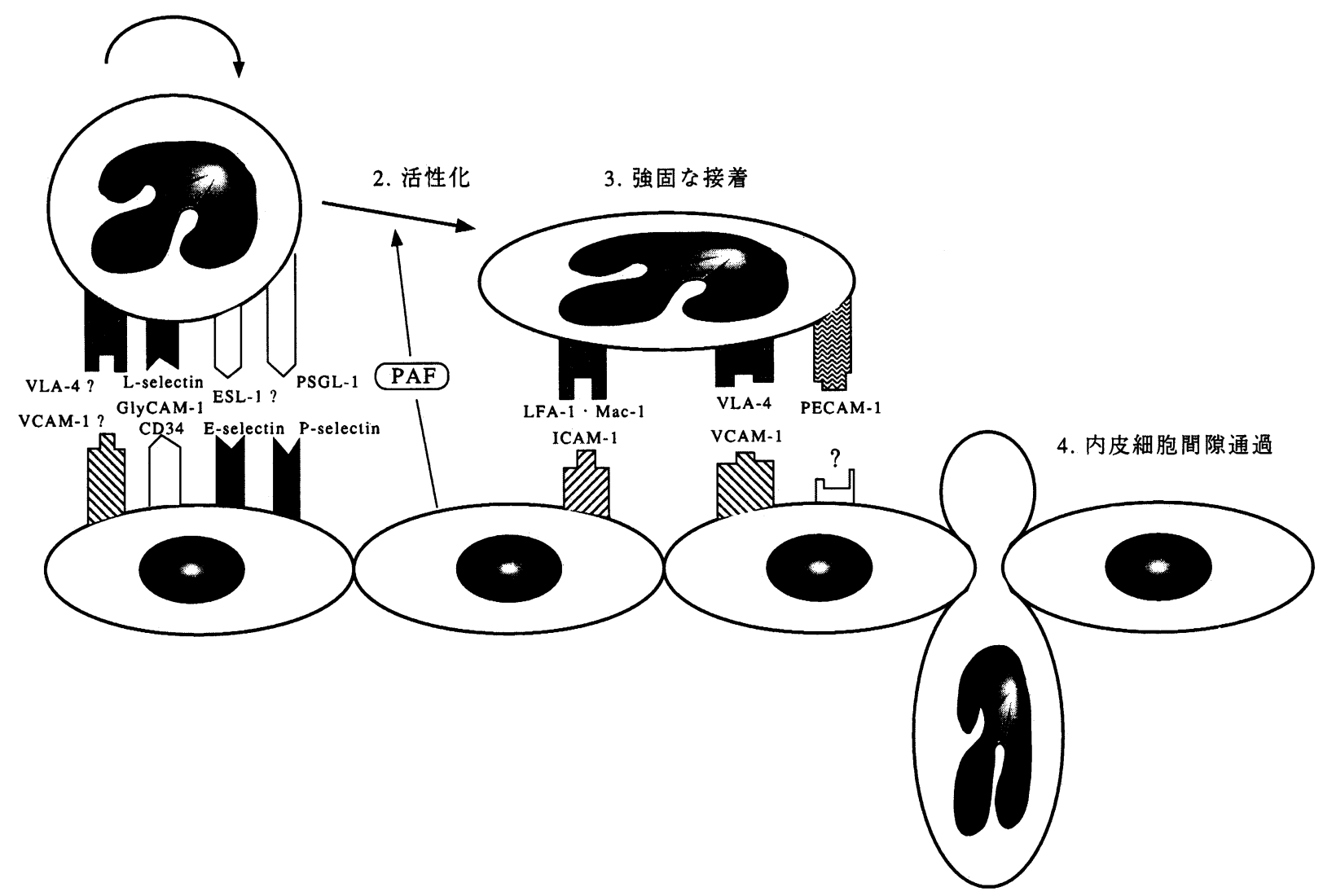

Fig. 2 白血球の血管外浸潤の分子機構.

が参加するに至り，ローリングを示す白血球は著増する． ここで，P-セレクチンは内皮細胞の Weibel-Palade body の 顆粒膜糖蛋白として貯蔵されており，トロンビンやヒスタ ミン刺激による脱顆粒現象に伴い数分以内に細胞表面に発 現し，1〜3時間程度でふたたび細胞内に取り込まれる.— 方，E-セレクチンは炎症性サイトカイン刺激により数時間 で誘導される (前述).したがってこの発現刺激, 発現様式 の相違が両者の役割分担を明確にしていると考えられる。 この (1)の過程において白血球側が活性化をうける (2) 可能性が考えられており，ここには内皮細胞表面の血小板 活性化因子 (PAF) などが関与する ${ }^{6}$. (2) に伴い，L-セレ クチンは sheddingにより細胞表面から脱落し, 一方, イン テグリンファミリーの分子である Mac-1 の細胞表面への 表出がおこる.また，Mac-1 や LFA-1 は白血球の活性化に さいして，おそらく高次構造変化により， avidity を克進さ せる.これにより内皮細胞表面に発現している ICAM-1 と の間に (3)のステップを成立させることが可能となる．こ の段階は (1) とは異なり非可逆的とされ，その後 1 時間以 内に PECAM-1 を介して (4)へと進んでいく.

\section{V. 接着分子の測定法}

粥状硬化巣をはじめとした各病変部における接着分子 の発現は, 主に間接蛍光抗体法で検討されている.しかし 発現の強弱をみるにとどまり，定量化はされていない．し かし, 接着分子は水解酵素による切断, 細胞膜を含んだ微 小顆粒として，あるいは alternative splicing により可溶型 (s：soluble) 分子を形成する (Fig. 3). この可溶型接着分子 は血清・血漿をはじめ, 胸水, 髄液, 関節液などに認めら れ，ELISAにより定量的に測定され，普及している。 たと えば可溶型セレクチン分子では，健常人でも sL-セレクチ ンが $1.6 \pm 0.8 \mu \mathrm{g} / \mathrm{ml}$ (血清) $)^{7}$, $\mathrm{sE}$-セレクチンが $0.92 \pm 0.66$ $\mathrm{ng} / \mathrm{ml}\left(\right.$ 血清 $^{8)}$, sP-セレクチンが $121 \pm 84 \mathrm{ng} / \mathrm{ml}$ (血漿) ${ }^{9)}$ の濃度でそれぞれ検出されており，さまざまな疾患で高值 となることが報告され，特に $\mathrm{sE}$-および $\mathrm{sP}$-セレクチンは血 管病変を反映すると考えられている。 しかし多くの可溶型 分子が蛋白分解により非特異的に産生されることから，こ れらの疾患特異性や活動性との関連，さらにこれらの点に おける既存のマーカーとの比較など，臨床応用にはまだ多 くの課題が残されている. 
1)

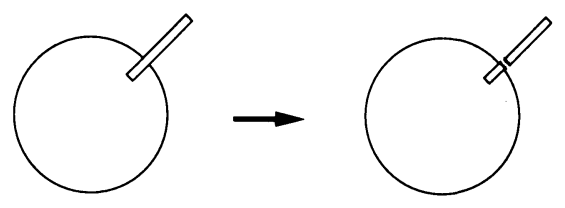

2)

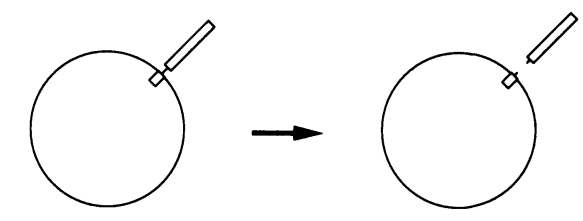

3)

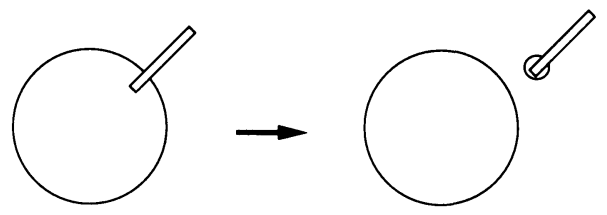

4)

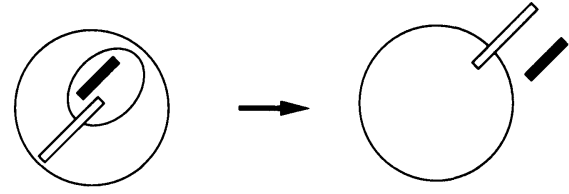

Fig. 3 可溶型接着分子の生成機序. 1) 蛋白分解醅素による 細胞外領域の切断 2) PI-PLCによる加水分解 3) microvesicle の形成 4) alternative splicing（産物を黒 で示す).

\section{VI. 病理的ないし臨床的意義 ——動脈硬化との関連 —}

Cybulsky らは, LPS で刺激したウサギの内皮細胞に, 単 核球 (単球とリンパ球) の接着を特異的に誘導する, ヒト VCAM-1に相同性の高い $118 \mathrm{kD}$ および $98 \mathrm{kD}$ の分子 (ATHERO-ELAMs) を見出し，さらに高コレステロール 食を負荷したウサギ，および遺伝的に機能的 LDL レセプ ターを欠損したウサギを，動脈硬化のモデル動物として免 疫組織学的に検討し, この分子が病変局所に発現している ことを示した ${ }^{10)}$.さらにウサギ大動脈における動脈硬化の 経時的検討を行い, 高コレステロール食負荷の 1 週間後に 内皮細胞表面の VCAM-1 の発現，3 週間後には VCAM-1 発現内皮細胞下へのマクロファージの浸潤を認めた ${ }^{11}$.

一方, ヒトの動脈硬化斑 (より進展した線維化斑を除く) では, ICAM-1 の発現増強が内皮細胞，平滑筋細胞，マク ロファージに認められ，内皮細胞では ICAM-1 より弱いな がら，E-セレクチンおよび P-セレクチンの発現が認められ ている ${ }^{12-14)}$. そして実際に単球の病変部位への選択的な接 着が認められ，この接着は CD18や ICAM-1 に対する抗体 で阻害された (内皮細胞への接着はP-セレクチンに対す
る抗体でも少し抑制 $)^{15)}$.

こうした接着分子の多くは前述の炎症性サイトカイン で発現誘導されるが, probucol などの抗酸化㓮投与により WHHL ウサギの動脈硬化の進展が抑制されたことから, 酸化 LDL の動脈硬化における重要性が確認された ${ }^{16)}$. In vitro の実験系でも, 酸化変性をうけた LDLとインキュ ベートしたウサギの動脈内皮細胞は, 単球の走化性因子を 産生し, かつ単球との接着性が増強された ${ }^{17)}$. しかもこの酸 化変性で著増するリゾホスファチジルコリン (lyso-PC) が，ウサギおよびヒトの動脈内皮細胞において，VCAM-1 と ICAM-1 の発現六進を介して単球の接着を増強させ $た^{18)}$.さらに酸化変性 LDL は TNF $\alpha$ 刺激による両接着分 子の発現に対する増強効果も示した ${ }^{199}$. 他方, HDL は酸化 変性 LDL による U937 の内皮細胞への接着増強を抑制す ることが示されたが，この接着は ICAM-1, VCAM-1, E-セ レクチンのいずれにもよらないらしく20), 今後の検討が待 たれる。

\section{文献}

1) McEver RP : Leukocyte interactions mediated by selectins. Thromb Haemost, 66: 80-87, 1991

2) Springer TA : Adhesion receptors of the immune system. Nature, 346: 425-434, 1990

3) Hynes RO : Integrins ; versality, modulation, and signaling in cell adhesion. Cell, 69: 11-25, 1992

4) Steegmaier $M$, Levinovitz A, Isenmann $S$, Borges $E$, Lenter M, Kocher HP, Kleuser B, and Vestweber D : The E-selectin-ligand ESL-1 is a variant of a receptor for fibroblast growth factor. Nature, 373: 615-620, 1995

5) Butcher EC: Leukocyte-endothelial cell recognition : Three (or more) steps to specificity and diversity. Cell, 67: 1033-1036, 1991

6) Lorant DE, Topham MK, Whatley RE, McEver RP, McIntyre TM, Prescott SM, and Zimmerman GA: Inflammatory roles of P-selecton. J Clin Invest, 92 : 559-570, 1993

7) Schleiffenbaum B, Spertini O, and Tedder TF : Soluble L-selectin is present in human plasma at high levels and retains functional activity. J Cell Biol, 119: 229-238, 1992

8) Newman W, Beall LD, Carson CW, Hunder GG, Graben N, Randhawa ZI, Gopal TV, Wiener-Kronish J, and Matthay MA : Soluble E-selectin is found in supernatants of activated endothelial cells and is elevated in the serum of patients with septic shock. J Immunol, 150: 644-654, 1993

9) Katayama M, Handa M, Araki Y, Ambo H, Kawai Y, Watanabe K, and Ikeda Y : Soluble P-selectin is present in normal circulation and its plasma level is elevated in patients with thrombotic thrombocytopenic purpura and haemolytic uraemic syndrome. $\mathrm{Br} \mathrm{J}$ Haematol, 84 : 702-710, 1993

10) Cybulsky MI and Gimbrone MA Jr: Endothelial 
expression of a mononuclear leukocyte adhesion molecule during atherogenesis. Science, 251: 788-791, 1991

11) Li H, Cybulsky MI, Gimbrone MA Jr, and Libby P : An atherogenic diet rapidly induces VCAM-1, a cytokine-regulatable mononuclear leukocyte adhesion molecule, in rabbit aortic endothelium. Arterioscler Thromb, 13: 197-204, 1993

12) Poston RN, Haskard DO, Coucher JR, Gall NP, and Johnson-Tidey RR : Expression of intercellular adhesion molecule-1 in atherosclerotic plaques. Am J Pathol, 140: 665-673, 1992

13) van der Wal AC, Das PK, Tigges AJ, and Becker AE : Adhesion molecules on the endothelium and mononuclear cells in human atherosclerotic lesions. Am J Pathol, 141 : 1427-1433, 1992

14) Berliner JA, Territo MC, Sevanian A, Ramin S, Kim JA, Bamshad B, Esterson M, and Fogelman AM : Minimally modified low density lipoprotein stimmulates monocyte endothelial interactions. J Clin Invest, 85 : 1260-1266, 1990

15) Johnson-Tidey RR, McGregor JL, Taylor PR, and Poston RN: Increase in the adhesion molecule Pselectin in endothelium overlying atherosclerotic plaques; coexpression with intercellular adhesion molecule-1. Am J Pathol, 144 : 952-961, 1994
16) Poston RN and Johnson-Tidey RR: Localized adhesion of monocytes to human atherosclerotic plaques demonstrated in Vitro; Implications for atherogenesis. Am J Pathol, 149: 73-80, 1996

17) Kita $T$, Nagano $Y$, Yokode $M$, Ishii $K$, Kume $N$, Ooshima A, Yoshida $\mathrm{H}$, and Kawai C: Probucol prevents the progression of atherosclerosis in Watanabe heritable hyperlipidemic rabbit, an animal model for familial hypercholesterolemia. Proc Natl Acad Sci USA, 84 : 5928-5931, 1987

18) Kume N, Cybulsky MI, and Gimbrone MA Jr : Lysophosphatydilcholine, a component of atherogenic lipoproteins, induces mononuclear leukocyte adhesion molecules in cultured human and rabbit arterial endothelial cells. J Clin Invest, 90: 1138-1144, 1992

19) Khan BV, Parthasarathy SS, Alexander RW, and Medford RM: Modified low density lipoprotein and its constituents augment cytokine-activated vascular cell adhesion molecule-1 gene expression in human vascular endothelial cells. J Clin Invest, 95: 1262-1270, 1995

20) Maier JAM, Barenghi L, Pagani F, Bradamante S, Comi $P$, and Ragnotti $G$ : The protective role of high-density lipoprotein on oxidized-low-density-lipoprotein-induced U937/endothelial cell interactions. Eur J Biochem, 221 : 35-41, 1994 